\title{
Using the Patient Portal Sexual Health Instrument in Surveys and Patient Questionnaires Among Sexual Minority Men in the United States: Cross-sectional Psychometric Validation Study
}

\author{
Kevon-Mark P Jackman ${ }^{1}$, DrPH, MPH; Jeremy Kane ${ }^{2}$, PhD, MPH; Hadi Kharrazi ${ }^{3}$, PhD, MD; Renee M Johnson ${ }^{1}$, \\ $\mathrm{PhD}, \mathrm{MPH}$; Carl Latkin ${ }^{4}, \mathrm{MS}, \mathrm{PhD}$

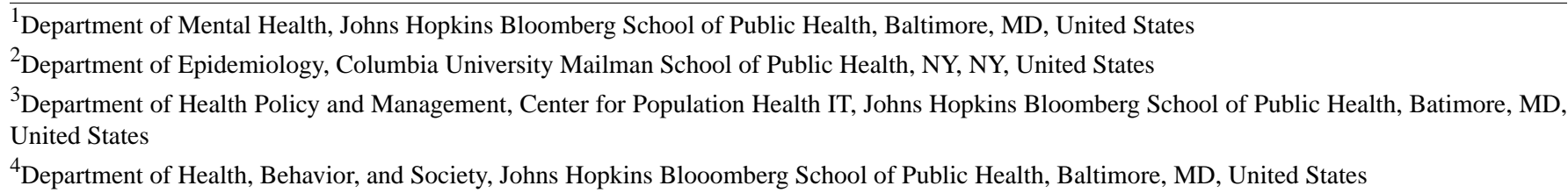

Corresponding Author:

Kevon-Mark P Jackman, DrPH, MPH

Department of Mental Health

Johns Hopkins Bloomberg School of Public Health

624 N Broadway

Hampton House 8th Floor

Baltimore, MD, 21205

United States

Phone: 14109553910

Email: kjackma2@jhmi.edu

\section{Related Article:}

This is a corrected version. See correction statement in: https://www.jmir.org/2021/3/e28358/

\section{Abstract}

Background: Patient portal modules, including electronic personal health records, health education, and prescription refill ordering, may be leveraged to address the sexually transmitted infection (STI) burden, including HIV, among gay, bisexual, and other sexual minority men (SMM). Theoretical frameworks in the implementation sciences highlight examining constructs of innovation attributes and performance expectations as key determinants of behavioral intentions and the use of new web-based health technologies. However, behavioral intentions to use patient portals for HIV and other STI prevention and care among SMM is understudied.

Objective: The aim of this study is to develop a brief instrument for measuring attitudes focused on using patient portals for STI prevention and care among a nationwide sample of SMM.

Methods: A total of 12 items of the American Men's Internet Survey-Patient Portal Sexual Health Instrument (AMIS-PPSHI) were adapted from a previous study. Psychometric analyses of the AMIS-PPSHI items were conducted among a randomized subset of 2018 AMIS participants reporting web-based access to their health records $(\mathrm{N}=1375)$. Parallel analysis and inspection of eigenvalues in a principal component analysis (PCA) informed factor retention in exploratory factor analysis (EFA). After EFA, Cronbach $\alpha$ was used to examine the internal consistency of the scale and its subscales. Confirmatory factor analysis (CFA) was used to assess the goodness of fit of the final factor structure. We calculated the total AMIS-PPSHI scale scores for comparisons within group categories, including age, STI diagnosis history, recency of testing, serious mental illness, and anticipated health care stigma.

Results: The AMIS-PPSHI scale resulting from EFA consisted of 12 items and had good internal consistency $(\alpha=.84)$. The EFA suggested 3 subscales: sexual health engagement and awareness $(\alpha=.87)$, enhancing dyadic communication $(\alpha=.87)$, and managing sexual health care $(\alpha=.79)$. CFA demonstrated good fit in the 3-factor PPSHI structure: root mean square error of approximation $=0.061$, comparative fit index $=0.964$, Tucker-Lewis index $=0.953$, and standardized root mean square residual $=0.041$. The most notable differences were lower scores on the enhanced dyadic communication subscale among people living with HIV. 
Conclusions: PPSHI is a brief instrument with strong psychometric properties that may be adapted for use in large surveys and patient questionnaires in other settings. Scores demonstrate that patient portals are favorable web-based solutions to deliver health services focused on STI prevention and care among SMM in the United States. More attention is needed to address the privacy implications of interpersonal use of patient portals outside of traditional health settings among persons with HIV.

(J Med Internet Res 2021;23(2):e18750) doi: 10.2196/18750

\section{KEYWORDS}

health information technology; sexual behavior; HIV; STI; patient portals

\section{Introduction}

\section{Psychometrics in Health Technology Behavior Research}

The use of digital strategies to address public health priorities, such as HIV, has increased tremendously in the United States in the last decade [1-4]. To inform implementation strategies, many survey instruments have been developed to measure contextual attitudes about health technology use across patient populations. The National Cancer Institute's Health Information National Trends Survey (HINTS) is a biennial nationally representative survey to assess the impact of the health information environment. It includes items useful to describe individual perceptions about the privacy and security of electronic medical records in a national sample [5]. Instrument development has been applied to assess attitudes about health technology use in specific populations, such as among older adults [6]. Psychometric constructs assessed within instruments are sometimes the basis of path models developed to measure behavioral intentions among consumers using health information technology, such as the Health Information Technology Acceptance Model [7]. This study focuses on developing an instrument for a neglected area of study, patient portal use for the prevention and care of sexually transmitted infections (STIs), including HIV.

\section{Patient Portals}

Patient portals provide patients with secure web-based access to health information, such as laboratory results and prescription medications. The web-based personal health information that a consumer accesses when using their patient portal is a type of health information technology (Health IT), referred to as personal health records (PHRs) [8,9]. Health IT is a broad concept that encompasses an array of technologies applied in health systems, such as PHRs, electronic health records (EHRs), or e-prescribing [10]. Logging on to a patient portal, users may message doctors, locate health education content, and a variety of options, depending on the Health IT platform. Certification for Health IT products is established by standards, implementation specifications, and certification criteria adopted by the US Secretary of Health and Human Services [11]. Data security and privacy measures, such as encrypting authentication credentials, are outlined within standards [12]. This is important because privacy concerns and mistrust are known barriers to PHR adoption [13,14]. Nevertheless, among US sexual minority men (SMM), patient portals are highly acceptable for delivery of comprehensive sexual health services that support HIV preventative behaviors, such as disclosing STI PHRs with sex partners $[15,16]$.
In a 2016 market of approximately 186 certified vendors, $92 \%$ of US hospitals contracted either Cerner, MEDITECH, Epic Systems, CPSI, McKesson, and MEDHOST to supply certified Health IT [17]. To be certified, EHR vendors must include a patient portal module and use Fast Healthcare Interoperability Resources specifications to allow communication across vendor platforms [12,18]. Examples of patient portals are Epic's MyChart, Veterans Administration's My HealtheVet, Geisinger's MyGeisinger, and Kareo's Kareo EHR Patient Portal. There are over 300 unique Health IT products with 2015 certification that allow patients (ie, consumers) to view, transmit, and download patient medical data to a third party [19]. PHR systems may also be standalone and untethered to a health system's EHR system [9].

As a result of federal incentive programs, namely, the Merit-Based Incentive Payment System programs Advancing Care Information, which have replaced Meaningful Use, patient portal access in health care settings has grown exponentially in the last decade and provides an excellent opportunity to deliver important health communications to patients [20-22]. By 2015, $95 \%$ of hospitals and $63 \%$ of office-based physicians had IT solutions allowing patients to view web-based health records $[22,23]$. Patient medical records are often perceived as highly private and only to be viewed by the patient and authorized representatives, which are based on important ethical and societal concerns of privacy [24-26]. However, portals also allow patients to interpersonally use information in PHRs outside of health care settings, such as sharing laboratory results or prescriptions with family, friends, and partners when promoting health behaviors [27]. Furthermore, few empirical studies have measured the preferences for and potential health benefits of the patient portal for sexual health and well-being on both individual and interpersonal levels.

\section{The Utility of Patient Portals for STIs}

To date, little information is available on patients' perceptions of patient portals and their potential use for the prevention and care of STIs, including HIV [28-30]. STIs are substantial public health problems, and they may be particularly well suited for prevention and management with patient portals. With billions of dollars in US health care costs, an estimated 20 million new infections each year, and as major causes of preventable disease, STIs are serious and growing public health threats [31]. In 2018, there were 2,457,118 combined cases of chlamydia, gonorrhea, and syphilis alone in the United States, continuing the trend of record-breaking numbers within the last decade [32]. The increasing prevalence of multidrug-resistant gonorrhea and the rise in syphilis infections also signal the urgent need for more effective prevention strategies $[33,34]$. 
Inefficient access and adherence to HIV medication among people living with HIV and pre-exposure prophylaxis (PrEP) among some SMM risk groups contribute to the burden of new HIV infections. In fact, persons with HIV who attain virologic suppression cannot transmit HIV to others, as regular PrEP use can effectively prevent the acquisition of HIV infection $[35,36]$. Adherence requires compliance with outpatient provider visits, filling in prescriptions, and taking antiretroviral therapy (ART) or PrEP over time; however, nonadherence can increase HIV disease progression and risk of disease transmission. Patient portals may effectively be able to create an easy-to-use system for organizing health information and be helpful in engaging SMM in care on all fronts of HIV infection.

Given the stigma about same-sex sexuality and talking about HIV and STIs, portals can also bridge communication gaps with providers and sex partners. According to the Centers for Disease Control and Prevention, gay, bisexual, and other SMM are disproportionately impacted by syphilis, HIV, and other STIs $[37,38]$. Factors such as patient-provider communication barriers and anticipated health care stigma experienced among SMM are known to hinder the use of STI preventive services such as testing [39-41]. In addition, controlling HIV is harder among persons with mental health issues, resulting in lower rates of HIV virologic suppression $[42,43]$. In a call to action for comprehensive HIV services for SMM, Beyrer et al [44] recommend health providers to provide integrated mental health services for SMM. SMM today have demonstrated high acceptability of medical and public health practice supported by mobile devices or mobile health (mHealth) in HIV interventions; however, these solutions have largely operated outside of the Health IT aegis of EHR and integrated PHR systems [45]. Previous studies examining perceptions of patient portal use for HIV care and STI prevention have demonstrated high acceptability and concern about potential breaches of privacy $[28,30,46]$.

\section{Study Purpose}

With this changing environment, new studies continue to burgeon modeling the implementation of health innovations for behavioral interventions focused on SMM. However, little data are available on the attributes and expectations of patient portals among SMM broadly across the United States. Theoretical frameworks, such as the Diffusion of Innovation theory and the extended unified theory of adoption and use of technology, are often used in behavioral sciences to inform implementation of new health technologies across consumer populations $[6,47,48]$. The theories posit that attributes of health technology and performance expectations are drivers of behavioral intentions to use health technology, and further behavioral intentions and habits determine behaviors or patterns of use. At the foundation of optimizing the design and uptake of new health technologies is scaling consumer perceptions about technology. Therefore, the overall goal of this study is to evaluate the psychometrics and adaptation of an instrument for measuring attitudes about using patient portals for STI prevention and care. Within-group comparisons of instrument scale scores are examined for categorical variables, including age, US region, last STI test, STI diagnosis, anticipated health care stigma, and mental health status.

\section{Methods}

\section{Study Overview}

Data were obtained from the 2018 American Men's Internet Survey (AMIS). AMIS is an annual cross-sectional web-based survey of US residents who are aged at least 15 years; are cisgender male; and are gay or bisexual or have ever had sex with a man [49]. The study was conducted in compliance with federal regulations governing the protection of human subjects, and the study protocol was reviewed and approved by the Institutional Review Board at Emory University.

A randomized subset of 4647 AMIS participants was presented with survey items focusing on using patient portal services for STI prevention and care. Only survey participants reporting the ability to view their web-based health records were included in the analysis. Of these 2566 participants with patient portal access, the participants with do not know and refuse to answer responses on patient portal items were excluded from the analysis, resulting in a final analytic sample of 1375 men.

\section{Measures and Instrument Development}

The Patient Portal Sexual Health Instrument (PPSHI) is a scale designed to evaluate perceptions of using patient portals to promote STI prevention and care behaviors. Items were originally adapted from a study among coed students at a historically Black university characterizing the perceived role of patient portals in supporting STI prevention behaviors- the Electronic Sexual Health Information Notification and Education (eSHINE) Study. In total, the eSHINE Study-Patient Portal Instrument (eSHINE-PPI) consisted of 19 items representing 4 subscales: (1) sexual health engagement (4 items), (2) informational resource compatibility (3 items), (3) valuation of services (5 items), and (4) PHR impact ( 7 items). A complete list of eSHINE-PPI items, factor loadings corresponding to unique subscales, and reliability coefficients can be found in Multimedia Appendix 1 [29,50]. To explore a more parsimonious instrument, we adapted 12 items from 3 eSHINE-PPI subscales to a nationwide survey of SMM. We focused on eliminating the eSHINE-PPI subscale items with the lowest factor loadings. Responses were also reduced from 7-point Likert scales to 4-point ordinal scales. We then adapted the eSHINE-PPI instrument to the AMIS-2018 survey.

\section{Adapting the Sexual Health Engagement Subscale}

The lowest loading item on the sexual health engagement subscale, "I plan to manage my medical records with PHRs in the future," was eliminated. The final adapted subscale ( 3 items) measured perceived attributes of using (vs not using) patient portals, specifically that (1) it is a more convenient way to manage my sexual health records, (2) it encourages people to be more aware of their sexual health, and (3) it will help people like me make better sexual health decisions. Responses were coded as follows: $0=$ strongly disagree, $1=$ disagree, $2=$ agree, and $3=$ strongly agree. Possible scores ranged from 0 to 9 .

\section{Adapting the PHR Impact Subscale}

The following 4 items were eliminated from the PHR impact subscale: (1) PHRs make it easier for people to routinely have 
check-in conversations with partners about STI prevention, (2) Partners using PHRs will start talking about STI prevention earlier in a relationship, (3) I would have more discussions with partners about STI testing if PHRs were more commonly used, and (4) Using PHRs with a partner builds trust. The final adapted subscale (3 items) measured agreement with beliefs that sharing STI PHRs with partners will (1) improve communication on HIV and other STIs, (2) improve confidence in the testing information a partner share, and (3) improve control over my sexual health and decision making. These responses were coded as follows: $0=$ definitely not, $1=$ probably not, $2=$ probably, and $3=$ definitely. Possible scores ranged from 0 to 9 .

\section{Adapting the Valuation of Services Subscale}

The item In addition to electronic sexually transmitted disease (STD) results, which services are important for PHRs to include: Access to all of your medical records was eliminated from the valuation of services subscale. Given the increase in telehealth success, the Services to communicate with your doctor or health professionals item was modified to specify video chat services to communicate with health care providers [51,52]. In response to recent decade increases in the use of interactive games to improve HIV prevention behaviors and the use of home test kits for STI screening, we added 2 items assessing valuation for games to promote sexual health and the ability to order home test kits for HIV and STDs to the valuation of services subscale [45,53-58]. For the final adapted subscale (6 items), participants were asked to rate the value of 6 patient portal features: (1) games to promote sexual health, (2) ability to order home test kits for STIs, (3) counseling and resources for people with STIs, (4) telehealth services, (5) ability to locate STI testing centers, and (6) tips or tools for managing sexual health. Responses on patient portal functionality items were coded as follows: $0=$ no value, $1=$ low value, $2=$ moderate value, and 4=high value. Possible scores ranged from 0 to 18 .

The Informational Resource Compatibility Subscale (3 items) was not adapted to AMIS. Possible scores for the total AMIS-PPSHI ranged from 0 to 36 .

\section{Statistical Analysis}

First, we conducted a principal component analysis (PCA) of the 12 items to estimate an appropriate number of factors to retain. The retention of factors was determined by a parallel analysis and examining eigenvalues greater than 1.0 [59]. We used the exploratory factor analysis (EFA) to estimate the factor structure and loadings. Item loadings were examined for each factor using cutoff values $\geq 0.50$. Sampling adequacy was indicated by a Kaiser-Meyer-Olkin (KMO) score greater than $0.80[60]$.

We estimated the overall scale and subscale internal reliability with Cronbach $\alpha$ for the new AMIS-PPSHI. Confirmatory factor analysis (CFA) was used to evaluate measures of fit, including the Tucker-Lewis index (TLI), the comparative fit index (CFI), the root mean square error of approximation (RMSEA), and the standardized root mean square residual (SRMR). Thresholds for fit statistics were values close to 0.95 for TLI and CFI, values close to 0.08 for SRMR, and values close to 0.06 for RMSEA [61]. For standardized factor loadings, we used a cutoff of 0.50 [62].

We calculated the total AMIS-PPSHI scale scores for comparisons within group categories, including age, STI diagnosis history, recency of testing, serious mental illness, and anticipated health care stigma. The Kessler 6-item (K6) scale for psychological distress was used to determine the presence of serious mental illness (score 13 or greater) [63]. Anticipated health care stigma was defined as whether the participant was ever afraid to seek health care services because of worrying that someone may learn they have sex with men. Two-sample $t$ tests were used to compare binary group differences in scale scores using a $P$ value of .05 as the criterion for statistical significance. Analysis of variance (ANOVA) was used to compare group differences in scale scores for variables with more than 2 groups, also using a $P$ value of .05 as the criterion for statistical significance.

\section{Results}

\section{Sample Description}

The sample consisted of 1375 US SMM with a median age of 34 years and an IQR of 25 to 50 years. The demographic characteristics of the study sample are presented in Table 1. Table 2 presents the items included in the questionnaire with calculated mean and mode scores. The KMO score (0.8492) established sampling adequacy. We used a Promax rotation because the factor correlations exceeded 0.32 [64]. On the basis of eigenvalues above 1.0 and parallel analysis, we estimated a 3 -factor solution for factor analysis. Factor analysis yielded 3 distinct factors using the 0.50 cutoff and no cross-loading above 0.15 . 
Table 1. Demographic data for the study population, including age, region, and sexually transmitted infection diagnosis history, American Men's Internet Survey $2018(\mathrm{~N}=1375)$.

\begin{tabular}{|c|c|}
\hline Category & Participants, n (\%) \\
\hline \multicolumn{2}{|l|}{ Age (years) } \\
\hline $15-24$ & $318(23.13)$ \\
\hline $25-29$ & $214(15.56)$ \\
\hline $30-39$ & $291(21.16)$ \\
\hline$\geq 40$ & $552(40.15)$ \\
\hline \multicolumn{2}{|l|}{ US region } \\
\hline Northeast (eg, New York and Vermont) & $221(16.07)$ \\
\hline Midwest (eg, Illinois and Ohio) & $314(22.84)$ \\
\hline South (eg, Florida and Alabama) & $505(36.73)$ \\
\hline West (eg, California and Oregon) & $335(24.36)$ \\
\hline \multicolumn{2}{|l|}{ Race or ethnicity } \\
\hline Black, non-Hispanic & $75(5.51)$ \\
\hline Hispanic & $181(13.30)$ \\
\hline White, non-Hispanic & $1020(74.94)$ \\
\hline Other or multiple race & $85(6.25)$ \\
\hline \multicolumn{2}{|l|}{ History of $\mathrm{STI}^{\mathrm{a}}$ diagnosis } \\
\hline No history of HIV or other STI diagnosis & $1087(79.05)$ \\
\hline Living with HIV & $118(8.58)$ \\
\hline Recent gonorrhea, chlamydia, or syphilis (and not living with HIV) & $170(12.36)$ \\
\hline \multicolumn{2}{|l|}{ STI test in the 12 months before the study } \\
\hline No & $1128(82.04)$ \\
\hline Yes & $247(17.96)$ \\
\hline \multicolumn{2}{|l|}{ Willing to access web-based STI test results } \\
\hline No & $14(1.02)$ \\
\hline Yes & $1361(98.98)$ \\
\hline
\end{tabular}

${ }^{\mathrm{a}}$ STI: sexually transmitted infection. 
Table 2. Descriptive statistics of suggested instrument items, American Men's Internet Survey 2018 (N=1375).

\begin{tabular}{|c|c|c|}
\hline Questionnaire item & Mean (SD) & Mode \\
\hline \multicolumn{3}{|l|}{ Patient engagement with sexual health care items } \\
\hline Item 1. It is a more convenient way to manage my sexual health records. & $2.56(0.59)$ & 3 \\
\hline Item 2. It encourages people to be more aware of their sexual health. & $2.52(0.60)$ & 3 \\
\hline Item 3. It will help people like me make better sexual health decisions. & $2.37(0.71)$ & 2 \\
\hline \multicolumn{3}{|l|}{ Dyadic communication items } \\
\hline Item 4. Improve communication on HIV and other sexually transmitted infections & $2.49(0.65)$ & 3 \\
\hline Item 5. Improve my confidence in the testing information a partner shares with me & $2.54(0.63)$ & 3 \\
\hline Item 6. Improve control over my sexual health and decision making & $2.54(0.64)$ & 3 \\
\hline \multicolumn{3}{|l|}{ Conceptual features (functionality) } \\
\hline Item 7. Tips or tools for managing sexual health & $2.43(0.68)$ & 3 \\
\hline Item 8 . Ability to locate $\mathrm{STD}^{\mathrm{a}}$ test centers and services & $2.63(0.64)$ & 3 \\
\hline Item 9. Video chat for communicating with health care providers & $2.16(0.85)$ & 2 \\
\hline Item 10. Counseling and resources for people with STDs & $2.54(0.68)$ & 3 \\
\hline Item 11. Ability to order home test kits for HIV and STDs & $2.59(0.68)$ & 3 \\
\hline Item 12. Games to promote sexual health & $1.54(1.02)$ & 1 \\
\hline
\end{tabular}

${ }^{\mathrm{a}} \mathrm{STD}$ : sexually transmitted disease.

\section{The AMIS-PPSHI Structural Model}

Table 3 displays the 12 items and their respective loadings across the 3 factors. Items 1-3 loaded on a factor named sexual health engagement and awareness, reflecting the perceived attributes of using patient portals to engage in sexual health care. Items 4-6 loaded on a factor named enhancing dyadic communication, reflecting the perceived attributes of using STI PHRs to share testing history with partners. Items 7-12 loaded on a third factor named managing sexual health care, reflecting the desired functionality of patient portals. Inter-factor correlation were 0.42 between the sexual health engagement and awareness and enhancing dyadic communication factors. Sexual health engagement and awareness and managing sexual health care had a correlation of 0.29 . The estimated correlation between managing sexual health care and enhancing dyadic communication was 0.42 . The CFA results (Table 4) suggested good fit indices for the 3-factor model (RMSEA=0.061, CFI=0.964, TLI=0.953, SRMR=0.041, and coefficient of determination $=0.996$ ). 
Table 3. Exploratory factor analysis loadings and Cronbach $\alpha$ values, American Men's Internet Survey 2018 (N=1375).

\begin{tabular}{|c|c|c|c|}
\hline \multirow[t]{2}{*}{ Questionnaire item } & \multicolumn{3}{|l|}{ Factor loadings $^{\mathrm{a}, \mathrm{b}, \mathrm{c}}$} \\
\hline & $\begin{array}{l}\text { Factor } 1 . \text { Sexual health engage- } \\
\text { ment and awareness }\end{array}$ & $\begin{array}{l}\text { Factor } 2 . \text { Enhancing dyadic } \\
\text { communication }\end{array}$ & $\begin{array}{l}\text { Factor } 3 \text {. Managing sexual } \\
\text { health care }\end{array}$ \\
\hline $\begin{array}{l}\text { Item } 1 . \text { It is a more convenient way to manage my } \\
\text { sexual health records }\end{array}$ & 0.7994 & -0.0268 & -0.0061 \\
\hline $\begin{array}{l}\text { Item } 2 \text {. It encourages people to be more aware of } \\
\text { their sexual health }\end{array}$ & 0.8740 & -0.0231 & 0.0123 \\
\hline $\begin{array}{l}\text { Item 3. It will help people like me make better } \\
\text { sexual health decisions }\end{array}$ & 0.7374 & 0.1093 & 0.0224 \\
\hline $\begin{array}{l}\text { Item } 4 \text {. Improve communication on HIV and other } \\
\text { sexually transmitted infections }\end{array}$ & -0.0171 & 0.7773 & 0.0465 \\
\hline $\begin{array}{l}\text { Item } 5 \text {. Improve my confidence in the testing infor- } \\
\text { mation a partner shares with me }\end{array}$ & 0.0012 & 0.8213 & -0.0123 \\
\hline $\begin{array}{l}\text { Item } 6 . \text { Improve control over my sexual health and } \\
\text { decision making }\end{array}$ & 0.0494 & 0.8047 & -0.0226 \\
\hline Item 7. Tips or tools for managing sexual health & 0.0806 & 0.1323 & 0.5531 \\
\hline $\begin{array}{l}\text { Item } 8 \text {. Ability to locate } \mathrm{STD}^{\mathrm{d}} \text { test centers and ser- } \\
\text { vices }\end{array}$ & -0.0058 & -0.0348 & 0.6967 \\
\hline $\begin{array}{l}\text { Item } 9 . \text { Video chat for communicating with health } \\
\text { care providers }\end{array}$ & 0.0199 & -0.0478 & 0.6382 \\
\hline $\begin{array}{l}\text { Item 10. Counseling and resources for people with } \\
\text { STDs }\end{array}$ & 0.0208 & 0.0039 & 0.7415 \\
\hline $\begin{array}{l}\text { Item 11. Ability to order home test kits for HIV and } \\
\text { STDs }\end{array}$ & -0.0202 & -0.0057 & 0.5621 \\
\hline Item 12. Games to promote sexual health & -0.0743 & 0.0741 & 0.5269 \\
\hline
\end{tabular}

${ }^{\mathrm{a}}$ Factor loadings above 0.5000 are italicized.

${ }^{\mathrm{b}}$ Cronbach $\alpha$ for factors: factor 1 , sexual health engagement and awareness, $\alpha=.8678$; factor 2 , enhancing dyadic communication, $\alpha=.8689$; and Factor 3 , managing sexual health care, $\alpha=.7888$.

cInterfactor correlations: $\mathrm{r}_{\text {factor } 1 \text {,factor } 2}=0.42, \mathrm{r}_{\text {factor } 1 \text {,factor } 3}=0.29$, and $\mathrm{r}_{\text {factor } 2 \text {,factor } 3}=0.42$.

${ }^{\mathrm{d}} \mathrm{STD}$ : sexually transmitted disease. 
Table 4. Confirmatory factor analysis of standardized factor loadings for Patient Portal Sexual Health Instrument, American Men's Internet Survey 2018 (N=1375).

\begin{tabular}{|c|c|c|c|}
\hline \multirow[t]{2}{*}{ Questionnaire item } & \multicolumn{3}{|l|}{ Factor loadings } \\
\hline & $\begin{array}{l}\text { Sexual health engagement and } \\
\text { awareness }\end{array}$ & $\begin{array}{l}\text { Enhancing dyadic communi- } \\
\text { cation }\end{array}$ & $\begin{array}{l}\text { Managing sexual } \\
\text { health care }\end{array}$ \\
\hline $\begin{array}{l}\text { Item } 1 \text {. It is a more convenient way to manage my sexual } \\
\text { health records }\end{array}$ & 0.7929 & $\mathrm{~N} / \mathrm{A}^{\mathrm{a}}$ & N/A \\
\hline $\begin{array}{l}\text { Item 2. It encourages people to be more aware of their sexual } \\
\text { health }\end{array}$ & N/A & N/A & N/A \\
\hline $\begin{array}{l}\text { Item 3. It will help people like me make better sexual health } \\
\text { decisions }\end{array}$ & N/A & N/A & N/A \\
\hline $\begin{array}{l}\text { Item 4. Improve communication on HIV and other sexually } \\
\text { transmitted infections }\end{array}$ & N/A & 0.8119 & N/A \\
\hline $\begin{array}{l}\text { Item } 5 \text {. Improve my confidence in the testing information a } \\
\text { partner shares with me }\end{array}$ & N/A & 0.8429 & N/A \\
\hline $\begin{array}{l}\text { Item } 6 . \text { Improve control over my sexual health and decision } \\
\text { making }\end{array}$ & N/A & 0.8357 & N/A \\
\hline Item 7. Tips or tools for managing sexual health & N/A & N/A & 0.6633 \\
\hline Item 8 . Ability to locate $\mathrm{STD}^{\mathrm{b}}$ test centers and services & N/A & N/A & 0.6840 \\
\hline $\begin{array}{l}\text { Item } 9 \text {. Video chat for communicating with health care } \\
\text { providers }\end{array}$ & N/A & N/A & 0.6202 \\
\hline Item 10. Counseling and resources for people with STDs & N/A & N/A & 0.7760 \\
\hline Item 11. Ability to order home test kits for HIV and STDs & N/A & N/A & 0.5493 \\
\hline Item 12. Games to promote sexual health & N/A & N/A & 0.5339 \\
\hline
\end{tabular}

${ }^{\mathrm{a}} \mathrm{N} / \mathrm{A}$ : not applicable.

${ }^{\mathrm{b}} \mathrm{STD}$ : sexually transmitted disease.

\section{AMIS-PPSHI Scores}

Table 5 presents factor scores for AMIS-PPSHI total and Table 6 factor scores for AMIS-PPSHI subscales by group categories using the sum of scores for variables with factor loadings above a cutoff of 0.50 [65]. The mean $(\mathrm{M})$ and standard deviation (SD) AMIS-PPSHI total score was mean 28.94 (SD 5.14). Mean PPSHI subscale scores were as follows: sexual health engagement and awareness mean 7.46 (SD 1.70), enhancing dyadic communication mean 7.57 (SD 1.71), and managing sexual health care mean 13.90 (SD 3.22). By region, AMIS-PPSHI total scores were moderately higher than average in the South and West compared with the Northeast and Midwest regions. Mean AMIS-PPSHI scores decreased with increasing age category, most notably in the enhancing dyadic communication scale $\left(\mathrm{F}_{3,1371}=10.87 ; P<.001\right)$. Participants who were tested 12 months before the study had slightly higher mean scores on sexual health engagement and awareness, mean 7.52 (SD 1.66) versus mean 7.18 (SD 1.83), and enhancing dyadic communication, mean 7.62 (SD 1.69) versus mean 7.38 (SD 1.82). The largest difference in the AMIS-PPSHI score were in comparisons of participants according to their history of HIV or recent STI. The overall highest scores were among people without HIV and without recent STI. Participants living with HIV have the lowest overall AMIS-PPSHI mean scores, mean 27.57 (SD 5.89), primarily because of enhancing dyadic communication scores, mean 6.85 (SD 2.13). There are no significant differences in scores by anticipated health care stigma nor serious mental illness. However, scores were marginally higher among participants with a Kessler 6-item psychological distress scale (K6) score $\geq 13$. 
Table 5. Psychometrics of the Patient Portal Sexual Health Instrument by group, American Men's Internet Survey 2018 (N=1375).

\begin{tabular}{|c|c|c|c|c|c|}
\hline \multirow[t]{4}{*}{ Group } & \multicolumn{5}{|c|}{ AMIS-PPSHI $^{\mathrm{a}}$} \\
\hline & \multicolumn{5}{|l|}{ Total } \\
\hline & Cronbach $\alpha$ & Mean (SD) & Test statistic ${ }^{b}$ & & $P$ value \\
\hline & & & $F$ test (df) & $t$ test $(\mathrm{df})$ & \\
\hline All $(\mathrm{N}=1375)$ & .8430 & $28.94(5.14)$ & $N / A^{c}$ & N/A & N/A \\
\hline US region & & & $4.37(3,1371)$ & N/A & .005 \\
\hline Northeast (eg, New York and Vermont; $\mathrm{n}=221$ ) & .8208 & $28.35(4.88)$ & & & \\
\hline Midwest (eg, Illinois and Ohio; $n=314$ ) & .8529 & $28.29(5.46)$ & & & \\
\hline South (eg, Florida and Alabama; $\mathrm{n}=505$ ) & .8461 & $29.39(5.13)$ & & & \\
\hline West (eg, California and Oregon; $n=335$ ) & .8378 & $29.24(4.92)$ & & & \\
\hline Age category & & & $6.11(3,1371)$ & N/A & $<.001$ \\
\hline $15-24(n=318)$ & .8149 & $29.52(4.62)$ & & & \\
\hline $25-29(n=214)$ & .8095 & $29.44(4.57)$ & & & \\
\hline $30-39(n=291)$ & .8422 & $29.28(5.03)$ & & & \\
\hline$\geq 40(\mathrm{n}=552)$ & .8608 & $28.22(5.60)$ & & & \\
\hline STI $^{\mathrm{d}}$ test in 12 months before study & & & N/A & $1.64(1373)$ & .10 \\
\hline Yes $(n=1,128)$ & .8403 & $29.04(5.10)$ & & & \\
\hline No $(n=247)$ & .8548 & $28.45(5.28)$ & & & \\
\hline History of STI diagnosis & & & $7.89(2,1372)$ & N/A & $<.001$ \\
\hline No history of STI diagnosis $(\mathrm{n}=1087)$ & .8385 & $29.21(4.98)$ & & & \\
\hline Living with HIV ( $\mathrm{n}=118$ ) & .8617 & $27.57(5.89)$ & & & \\
\hline Recent gonorrhea, chlamydia, or syphilis and no HIV $(n=170)$ & .8437 & $28.13(5.36)$ & & & \\
\hline Anticipated health care stigma & & & N/A & $0.22(1373)$ & .83 \\
\hline No $(n=1037)$ & .8431 & $28.95(5.18)$ & & & \\
\hline Yes $(n=338)$ & .8433 & $28.88(5.02)$ & & & \\
\hline Serious mental illness & & & N/A & $1.76(1373)$ & .08 \\
\hline No $\left(\mathrm{K} 6^{\mathrm{e}}<13 ; \mathrm{n}=1113\right)$ & .8455 & $28.82(5.20)$ & & & \\
\hline Yes $(K 6 \geq 13 ; n=262)$ & .8288 & $29.44(4.82)$ & & & \\
\hline
\end{tabular}

${ }^{a}$ American Men's Internet Survey-Patient Portal Sexual Health Instrument.

${ }^{\mathrm{b}}$ Test statistic: for analysis of variance (ANOVA) the F-value (degrees of freedom groups, degrees of freedom residuals) test statistic is reported; for $t$ tests, the $t$ value (degrees of freedom) test statistic is reported.

${ }^{\mathrm{c}} \mathrm{N} / \mathrm{A}$ : not applicable.

${ }^{\mathrm{d}}$ STI: sexually transmitted infection.

${ }^{\mathrm{e}} \mathrm{K} 6$ refers to the Kessler 6-item psychological distress scale. 
Table 6. Psychometrics of the Patient Portal Sexual Health Instrument Subscales, by group, American Men's Internet Survey 2018 (N=1375).

\begin{tabular}{|c|c|c|c|c|c|c|c|c|c|c|c|c|}
\hline \multirow[t]{4}{*}{ Group } & \multicolumn{12}{|c|}{ AMIS-PPSHI ${ }^{\mathrm{a}}$ Subscales } \\
\hline & \multicolumn{4}{|c|}{$\begin{array}{l}\text { Sexual health engagement and } \\
\text { awareness }\end{array}$} & \multicolumn{4}{|c|}{ Enhancing dyadic communication } & \multicolumn{4}{|c|}{ Managing sexual health care } \\
\hline & \multirow{2}{*}{$\begin{array}{l}\text { Mean } \\
(\mathrm{SD})\end{array}$} & \multicolumn{2}{|c|}{ Test statistic ${ }^{\mathrm{b}}$} & \multirow{2}{*}{$\begin{array}{l}P \\
\text { value }\end{array}$} & \multirow{2}{*}{$\begin{array}{l}\text { Mean } \\
(\mathrm{SD})\end{array}$} & \multicolumn{2}{|c|}{ Test statistics ${ }^{\mathrm{b}}$} & \multirow{2}{*}{$\begin{array}{l}P \\
\text { value }\end{array}$} & \multirow{2}{*}{$\begin{array}{l}\text { Mean } \\
(\mathrm{SD})\end{array}$} & \multicolumn{2}{|c|}{ Test statistic ${ }^{\mathrm{b}}$} & \multirow{2}{*}{$\begin{array}{l}P \\
\text { value }\end{array}$} \\
\hline & & $\begin{array}{l}F \text { test } \\
(\mathrm{df})\end{array}$ & $\begin{array}{l}t \text { test } \\
\text { (df) }\end{array}$ & & & $\begin{array}{l}F \text { test } \\
(\mathrm{df})\end{array}$ & $\begin{array}{l}t \text { test } \\
(\mathrm{df})\end{array}$ & & & $\begin{array}{l}F \text { test } \\
(\mathrm{df})\end{array}$ & $\begin{array}{l}t \text { test } \\
(\mathrm{df})\end{array}$ & \\
\hline & $\begin{array}{l}7.46 \\
(1.70)\end{array}$ & N/A & N/A & N/A & $\begin{array}{l}7.57 \\
(1.71)\end{array}$ & N/A & N/A & N/A & $\begin{array}{l}13.90 \\
(3.22)\end{array}$ & N/A & N/A & N/A \\
\hline US region & & $\begin{array}{l}2.41 \\
(3,1371)\end{array}$ & N/A & .07 & & $\begin{array}{l}0.75 \\
(3,1371)\end{array}$ & N/A & .52 & & $\begin{array}{l}5.63 \\
(3,1371)\end{array}$ & N/A & $<.001$ \\
\hline $\begin{array}{l}\text { Northeast (eg, New York and } \\
\text { Vermont; } n=221 \text { ) }\end{array}$ & $\begin{array}{l}7.36 \\
(1.75)\end{array}$ & & & & $\begin{array}{l}7.43 \\
(1.68)\end{array}$ & & & & $\begin{array}{l}13.56 \\
(3.02)\end{array}$ & & & \\
\hline $\begin{array}{l}\text { Midwest (eg, Illinois and Ohio; } \\
\mathrm{n}=314 \text { ) }\end{array}$ & $\begin{array}{l}7.30 \\
(1.79)\end{array}$ & & & & $\begin{array}{l}7.55 \\
(1.77)\end{array}$ & & & & $\begin{array}{l}13.43 \\
(3.40)\end{array}$ & & & \\
\hline $\begin{array}{l}\text { South (eg, Florida and Alaba- } \\
\text { ma; } n=505 \text { ) }\end{array}$ & $\begin{array}{l}7.48 \\
(1.70)\end{array}$ & & & & $\begin{array}{l}7.63 \\
(1.67)\end{array}$ & & & & $\begin{array}{l}14.29 \\
(3.25)\end{array}$ & & & \\
\hline $\begin{array}{l}\text { West (eg, California and Ore- } \\
\text { gon; } n=335 \text { ) }\end{array}$ & $\begin{array}{l}7.64 \\
(1.55)\end{array}$ & & & & $\begin{array}{l}7.60 \\
(1.73)\end{array}$ & & & & $\begin{array}{l}14.00 \\
(3.06)\end{array}$ & & & \\
\hline Age category & & $\begin{array}{l}4.64 \\
(3,1371)\end{array}$ & N/A & .003 & & $\begin{array}{l}10.87 \\
(3,1371)\end{array}$ & N/A & $<.001$ & & $\begin{array}{l}1.47 \\
(3,1371)\end{array}$ & N/A & .22 \\
\hline $15-24(n=318)$ & $\begin{array}{l}7.51 \\
(1.55)\end{array}$ & & & & $\begin{array}{l}7.86 \\
(1.38)\end{array}$ & & & & $\begin{array}{l}14.15 \\
(3.20)\end{array}$ & & & \\
\hline $25-29(n=214)$ & $\begin{array}{l}7.70 \\
(1.44)\end{array}$ & & & & $\begin{array}{l}7.78 \\
(1.52)\end{array}$ & & & & $\begin{array}{l}13.96 \\
(2.99)\end{array}$ & & & \\
\hline $30-39(n=291)$ & $\begin{array}{l}7.59 \\
(1.65)\end{array}$ & & & & $\begin{array}{l}7.70 \\
(1.64)\end{array}$ & & & & $\begin{array}{l}13.99 \\
(3.09)\end{array}$ & & & \\
\hline$\geq 40(\mathrm{n}=552)$ & $\begin{array}{l}7.26 \\
(1.87)\end{array}$ & & & & $\begin{array}{l}7.26 \\
(1.93)\end{array}$ & & & & $\begin{array}{l}13.70 \\
(3.38)\end{array}$ & & & \\
\hline $\begin{array}{l}\text { STI }^{d} \text { test in } 12 \text { months before } \\
\text { study }\end{array}$ & & N/A & $\begin{array}{l}2.86 \\
(1373)\end{array}$ & .004 & & N/A & $\begin{array}{l}1.99 \\
(1373)\end{array}$ & .05 & & N/A & $\begin{array}{l}0.09 \\
(1373)\end{array}$ & .93 \\
\hline Yes $(n=1,128)$ & $\begin{array}{l}7.52 \\
(1.66)\end{array}$ & & & & $\begin{array}{l}7.62 \\
(1.69)\end{array}$ & & & & $\begin{array}{l}13.91 \\
(3.23)\end{array}$ & & & \\
\hline No $(n=247)$ & $\begin{array}{l}7.18 \\
(1.83)\end{array}$ & & & & $\begin{array}{l}7.38 \\
(1.82)\end{array}$ & & & & $\begin{array}{l}13.89 \\
(3.18)\end{array}$ & & & \\
\hline History of STI diagnosis & & $\begin{array}{l}1.02 \\
(2,1372)\end{array}$ & N/A & .36 & & $\begin{array}{l}12.25 \\
(2,1372)\end{array}$ & N/A & $<.001$ & & $\begin{array}{l}6.13 \\
(2,1372)\end{array}$ & N/A & .002 \\
\hline $\begin{array}{l}\text { No history of STI diagnosis } \\
(\mathrm{n}=1087)\end{array}$ & $\begin{array}{l}7.49 \\
(1.68)\end{array}$ & & & & $\begin{array}{l}7.66 \\
(1.64)\end{array}$ & & & & $\begin{array}{l}14.06 \\
(3.13)\end{array}$ & & & \\
\hline Living with HIV ( $\mathrm{n}=118)$ & $\begin{array}{l}7.39 \\
(1.72)\end{array}$ & & & & $\begin{array}{l}6.85 \\
(2.13)\end{array}$ & & & & $\begin{array}{l}13.33 \\
(3.64)\end{array}$ & & & \\
\hline $\begin{array}{l}\text { Recent gonorrhea, chlamydia, } \\
\text { or syphilis and no HIV }(n=170)\end{array}$ & $\begin{array}{l}7.30 \\
(1.78)\end{array}$ & & & & $\begin{array}{l}7.52 \\
(1.74)\end{array}$ & & & & $\begin{array}{l}13.31 \\
(3.41)\end{array}$ & & & \\
\hline Anticipated health care stigma & & N/A & $\begin{array}{l}0.47 \\
(1373)\end{array}$ & .64 & & N/A & $\begin{array}{l}1.02 \\
(1373)\end{array}$ & .31 & & N/A & $\begin{array}{l}0.35 \\
(1373)\end{array}$ & .73 \\
\hline No $(n=1037)$ & $\begin{array}{l}7.47 \\
(1.70)\end{array}$ & & & & $\begin{array}{l}7.60 \\
(1.74)\end{array}$ & & & & $\begin{array}{l}13.89 \\
(3.26)\end{array}$ & & & \\
\hline Yes $(n=338)$ & $\begin{array}{l}7.42 \\
(1.67)\end{array}$ & & & & $\begin{array}{l}7.49 \\
(1.63)\end{array}$ & & & & $\begin{array}{l}13.96 \\
(3.11)\end{array}$ & & & \\
\hline Serious mental illness & & N/A & $\begin{array}{l}0.68 \\
(1373)\end{array}$ & .49 & & N/A & $\begin{array}{l}1.79 \\
(1373)\end{array}$ & .07 & & N/A & $\begin{array}{l}1.58 \\
(1373)\end{array}$ & .11 \\
\hline
\end{tabular}




\begin{tabular}{|c|c|c|c|c|c|c|c|c|c|c|c|c|}
\hline \multirow[t]{4}{*}{ Group } & \multicolumn{12}{|c|}{ AMIS-PPSHI ${ }^{\mathrm{a}}$ Subscales } \\
\hline & \multicolumn{4}{|c|}{$\begin{array}{l}\text { Sexual health engagement and } \\
\text { awareness }\end{array}$} & \multicolumn{4}{|c|}{ Enhancing dyadic communication } & \multicolumn{4}{|c|}{ Managing sexual health care } \\
\hline & \multirow{2}{*}{$\begin{array}{l}\text { Mean } \\
\text { (SD) }\end{array}$} & \multicolumn{2}{|c|}{ Test statistic ${ }^{b}$} & \multirow{2}{*}{$\begin{array}{l}P \\
\text { value }\end{array}$} & \multirow{2}{*}{$\begin{array}{l}\text { Mean } \\
\text { (SD) }\end{array}$} & \multicolumn{2}{|c|}{ Test statistics ${ }^{b}$} & \multirow{2}{*}{$\begin{array}{l}P \\
\text { value }\end{array}$} & \multirow{2}{*}{$\begin{array}{l}\text { Mean } \\
\text { (SD) }\end{array}$} & \multicolumn{2}{|c|}{ Test statistic ${ }^{b}$} & \multirow{2}{*}{$\begin{array}{l}P \\
\text { value }\end{array}$} \\
\hline & & $\begin{array}{l}F \text { test } \\
(\mathrm{df})\end{array}$ & $\begin{array}{l}t \text { tes } \\
(\mathrm{df})\end{array}$ & & & $\begin{array}{l}F \text { test } \\
\text { (df) }\end{array}$ & $\begin{array}{l}t \text { test } \\
(\mathrm{df})\end{array}$ & & & $\begin{array}{l}F \text { test } \\
(\mathrm{df})\end{array}$ & $\begin{array}{l}t \text { test } \\
\text { (df) }\end{array}$ & \\
\hline No $\left(K 6^{\mathrm{e}}<13 ; \mathrm{n}=1113\right)$ & $\begin{array}{l}7.44 \\
(1.72)\end{array}$ & & & & $\begin{array}{l}7.53 \\
(1.75)\end{array}$ & & & & $\begin{array}{l}13.84 \\
(3.23)\end{array}$ & & & \\
\hline Yes $(\mathrm{K} 6 \geq 13 ; \mathrm{n}=262)$ & $\begin{array}{l}7.52 \\
(1.61)\end{array}$ & & & & $\begin{array}{l}7.74 \\
(1.51)\end{array}$ & & & & $\begin{array}{l}14.19 \\
(3.17)\end{array}$ & & & \\
\hline
\end{tabular}

\footnotetext{
aAmerican Men's Internet Survey-Patient Portal Sexual Health Instrument.

${ }^{\mathrm{b}}$ Test statistic: for analysis of variance (ANOVA) the F-value (degrees of freedom groups, degrees of freedom residuals) test statistic is reported; for $t$ tests, the $t$ value (degrees of freedom) test statistic is reported.

${ }^{\mathrm{c}}$ N/A: not applicable.

${ }^{\mathrm{d}} \mathrm{STI}$ : sexually transmitted infection.

${ }^{\mathrm{e}} \mathrm{K} 6$ refers to the Kessler 6-item psychological distress scale.
}

\section{Discussion}

\section{Principal Findings}

The goal of this study is to develop a brief instrument for measuring attitudes focused on using patient portals for STI prevention and care among a nationwide sample of SMM. HIV and other STIs are costly and have a high burden on SMM. Patient portals could be used to address risky sexual behaviors; however, past studies have not looked at service design and consumer adoption models for patient-facing IT solutions. Therefore, we created a brief instrument to enable the measurement of attitudes toward using patient portals for STI prevention and care among SMM with access to a patient portal. The instrument was adapted from earlier scientific work, is short, and may be added to health questionnaires focused on sexual health-related technology use. Furthermore, we demonstrated that AMIS-PPSHI might be adapted to include novel consumer-oriented features as technology evolves.

The resulting instrument consists of 12 items and 3 subscales measuring constructs of (1) sexual health engagement and awareness, (2) enhancing dyadic communication, and (3) managing sexual health care. Constructs cover unique aspects of patient portal use. First, portals should communicate personalized sexual health information to the user. Second, interpersonal use of patient portals may occur outside of health settings, particularly in events that share test histories with sexual partners. Third, patient portals should empower patients to engage with an array of sexual health care management services, such as testing and telehealth.

\section{A Closer Look at PPSHI}

PPSHI and its 3 subscales had a strong overall internal consistency. As expected, younger participants are more receptive to technology use. Scores have an indirect relationship with age; SMM aged 15-24 years had the highest scores. Scores stratified by STI diagnosis reveal interesting dynamics, most notably in the enhancing dyadic communication subscale. Scores on the enhancing dyadic communication subscale are the lowest among participants with HIV, an indicator of the highly stigmatized nature of HIV. Interpersonal use of patient portals with sexual partners may likely be lower for participants with HIV or other chronic STIs. Interventions are needed to reduce this stigma and to strengthen self-efficacy for discussing with partners the topics pertinent to sexual health and wellness.

Similar scores by anticipated health care stigma may be an indicator of acceptability of patient portals among participants who may be less likely to receive HIV care services [39,41]. Slightly higher AMIS-PPSHI scores among participants with mental health illness support the acceptability of the patient portal use among patients with mental health disorders [66]. Together with earlier studies, findings support patient portals as a promising avenue to plan interventions around increasing health engagement among marginalized groups, including persons with HIV $[28,30,46]$. The overall high mean sample score on AMIS-PPSHI may also indicate that patient portal interventions may extend to other areas of health care engagement, such as achieving hepatitis A and B vaccination and screening recommendations for SMM [67-69]. Messages delivered through patient portals have been demonstrated to increase herpes zoster vaccination in adults [70]. Thus, the current global climate of hepatitis A outbreak among SMM reflects missed opportunities to leverage patient portals to deliver hepatitis $\mathrm{A}$ and $\mathrm{B}$ vaccination screening messages to SMM [71-75]. The application of machine learning algorithms to identify PrEP candidates using EHR data may also be applied to identify candidates for hepatitis $\mathrm{A}$ and $\mathrm{B}$ vaccination; however, research is needed to develop efficacious algorithms [76].

\section{Strengths and Limitations}

The strength of AMIS-PPSHI is that it is based on empirical research, and it is very timely to the growing technology-based STI prevention models. The scale is shortened in item numbers and response options and still holds a strong internal consistency. The factor analysis is based on both an acceptable sample size of participants and the number of observed 
variables. Overall, the instrument performed statistically well in psychometric analysis. The age distribution of the sample offers some comparisons and extrapolation across groups of adolescent, young, and adult SMM. However, neither AMIS-PPSHI nor its subscales have been validated as constructs related to patterns of patient portal use for sexual health and wellness. Future validation studies may explore the relationship of constructs with patterns of patient portal use specific to sexual health and wellness. Clinical researchers may test the enhancing dyadic communication subscale as a determinant of an individual's likelihood to use PHRs for sharing STI test histories with main and nonmain partners [16]. The subscale may then be applied in clinical settings with decision analytics to identify patients for interventions that are less likely to disclose STI PHRs with partners. More data are needed on patterns of patient portal use for sexual health services such as viewing electronic STI test results, viewing health information on STIs, and ordering medications to prevent and treat STIs.

African American or Black SMM are notably underrepresented in the study sample. Future studies are needed to apply PPSHI across a broad nationwide sample of Black SMM and youth - the race or ethnic group most overburdened by HIV and other STI incidence and prevalence [34,38]. Additional validation studies are needed among other priority populations for STI prevention in the United States and other countries with burgeoning mHealth environments. A further limitation is that the instrument does not include items focused on the use of patient portals to report sexual health-related behaviors and outcomes. Ecological momentary assessment and patient-reported outcome measures are mechanisms that can feed data into patient portal systems and inform decision support algorithms for the user or health care providers [77-79]. Given the adaptability of PPSHI, items may be added to patient-reported outcomes to assess perceptions about reporting personal data to the patient portal for sexual health.

\section{Conclusions}

In summary, we suggest that PPSHI and its components could predict behavioral intentions and patterns for patient portal use for health behaviors related to STI prevention and care among SMM. PPSHI is feasibly adaptable to questionnaires and may have useful applications in electronic patient intake surveys. Short surveys on patient intake forms assessing risk behaviors have been used to inform clinical decision support algorithms, prompting providers to encourage STI screening for patients [80]. Assessing PPSHI constructs in patients may similarly be useful in informing provider messaging within decision support algorithms, for example, encouraging patients to share STI PHRs with partners.

\section{Acknowledgments}

The authors thank Dr Stefan Baral at Johns Hopkins University (Baltimore, MD, USA) and Dr Travis Sanchez at Emory University (Atlanta, GA, USA) for generously creating space for this research in the 2018 American Men's Internet Survey. This work was supported by grants from the MAC AIDS Fund and by the National Institutes of Health (P30AI050409), the Emory Center for AIDS Research, and the Johns Hopkins Bloomberg School of Public Health Center for Public Health and Human Rights (5R01MH110358-03). KJ's efforts were supported, in part, by T32DA007292 and R25MH08362.

\section{Authors' Contributions}

All listed authors contributed meaningfully to manuscript writing and revision in preparation for peer review submission. KJ analyzed the data and drafted the paper as the first author.

\section{Conflicts of Interest}

None declared.

\section{Multimedia Appendix 1}

Electronic Sexual Health Information Notification and Education (eSHINE) Study Patient Portal Instrument, 2014-2016, N=35. [DOCX File, 17 KB-Multimedia Appendix 1]

\section{References}

1. Horvath KJ, Alemu D, Danh T, Baker JV, Carrico AW. Creating Effective Mobile Phone Apps to Optimize Antiretroviral Therapy Adherence: Perspectives From Stimulant-Using HIV-Positive Men Who Have Sex With Men. JMIR mHealth uHealth 2016 Apr 15;4(2):e48. [doi: 10.2196/mhealth.5287]

2. Horvath KJ, Lammert S, MacLehose RF, Danh T, Baker JV, Carrico AW. A Pilot Study of a Mobile App to Support HIV Antiretroviral Therapy Adherence Among Men Who Have Sex with Men Who Use Stimulants. AIDS Behav 2019 Jul 15;23(11):3184-3198. [doi: 10.1007/s10461-019-02597-3]

3. Horvath KJ, Amico KR, Erickson D, Ecklund AM, Martinka A, DeWitt J, et al. Thrive With Me: Protocol for a Randomized Controlled Trial to Test a Peer Support Intervention to Improve Antiretroviral Therapy Adherence Among Men Who Have Sex With Men. JMIR Res Protoc 2018 May 31;7(5):e10182. [doi: 10.2196/10182]

4. Bauermeister JA, Golinkoff JM, Horvath KJ, Hightow-Weidman LB, Sullivan PS, Stephenson R. A Multilevel Tailored Web App-Based Intervention for Linking Young Men Who Have Sex With Men to Quality Care (Get Connected): Protocol for a Randomized Controlled Trial. JMIR Res Protoc 2018 Aug 02;7(8):e10444. [doi: 10.2196/10444] 
5. Office of the National Coordinator for Health Information Technology (ONC). Individuals' Perceptions of the Privacy and Security of Medical Records and Health Information Exchange. Health IT Quick-Stat \#58; Accessed 02/16/2020, 2020. 2019. URL: https://dashboard.healthit.gov/quickstats/pages/consumers-privacy-security-medical-record-information-exchange. php [accessed 2021-01-09]

6. Anderberg P, Eivazzadeh S, Berglund JS. A Novel Instrument for Measuring Older People's Attitudes Toward Technology (TechPH): Development and Validation. J Med Internet Res 2019 May 23;21(5):e13951. [doi: 10.2196/13951]

7. Kim J, Park H. Development of a Health Information Technology Acceptance Model Using Consumers' Health Behavior Intention. J Med Internet Res 2012 Oct 01;14(5):e133. [doi: 10.2196/jmir.2143]

8. ONC. What is a personal health record? Healthit.gov. 2016. URL: https://www.healthit.gov/faq/what-personal-health-record-0 [accessed 2021-01-09]

9. ONC. What is a patient portal? Healthit.gov. 2017. URL: https://www.healthit.gov/faq/what-patient-portal [accessed 2021-01-09]

10. ONC. What is Health IT? Healthit.gov. 2019. URL: https://www.healthit.gov/faq/what-health-it [accessed 2021-01-09]

11. ONC. About The ONC Health IT Certification Program. Healthit.gov. 2020. URL: https://www.healthit.gov/topic/ certification-ehrs/about-onc-health-it-certification-program [accessed 2021-01-09]

12. ONC. 2015 Edition Health Information Technology (Health IT) Certification Criteria, 2015 Edition Base Electronic Health Record (EHR) Definition, and ONC Health IT Certification Program Modifications. Federal Register 2015;80(200):16804-16921. [doi: 10.1007/springerreference 82314] [Medline: 26477063]

13. Jackman KP, Hightow-Weidman L, Poteat T, Wirtz AL, Kane JC, Baral SD. Evaluating psychometric determinants of willingness to adopt sexual health patient portal services among black college students: A mixed-methods approach. Journal of American College Health 2019 Nov 11:1-8. [doi: 10.1080/07448481.2019.1660352] [Medline: $\underline{31710578]}$

14. Hoque MR, Bao Y, Sorwar G. Investigating factors influencing the adoption of e-Health in developing countries: A patient's perspective. Informatics for Health and Social Care 2016 Feb 11;42(1):1-17. [doi: 10.3109/17538157.2015.1075541] [Medline: 26865037]

15. Jackman K, Latkin CA, Maksut JL, Trent ME, Sanchez TH, Baral SD. Patient Portals as Highly Acceptable Tools to Support HIV Preventative Behaviors Among Adolescent and Young Sexual Minority Men. Journal of Adolescent Health 2020 Aug;67(2):278-281. [doi: 10.1016/j.jadohealth.2020.03.029] [Medline: 32387095]

16. Jackman KM, Dangerfield DT, Yang C, Trent M, Kharrazi H, Johnson RM, et al. Behavioral intentions to use patient portals to disclose HIV and other sexually transmitted infection testing histories with sexual partners among US sexual minority men. AIDS Behav 2020 Nov 13:-. [doi: 10.1007/s10461-020-03092-w] [Medline: 33185776 ]

17. ONC. Certified Health IT Developers and Editions Reported by Hospitals Participating in the Medicare EHR Incentive Program, Health IT Quick-Stat \#29. Healthit.gov. 2017. URL: https://dashboard.healthit.gov/quickstats/pages/ FIG-Vendors-of-EHRs-to-Participating-Hospitals.php [accessed 2021-01-09]

18. ONC. $\$ 170.315(\mathrm{~g})(8)$ Application access — data category request. Healthit.gov. 2020. URL: https://www.healthit.gov/ test-method/application-access-data-category-request [accessed 2021-01-09]

19. ONC. Number of 2015 Edition Unique Products certified to specific Certification Criteria. Healthit.gov. URL: https://chpl. healthit.gov/\#/charts [accessed 2020-01-09]

20. ONC. Advancing Care Information Reporting: Successfully Report on Your MACRA Advancing Care Information Measures Using Certified Health IT. Healthit.gov. 2019. URL: https://www.healthit.gov/topic/federal-incentive-programs/MACRA/ MIPS/advancing-care-information-reporting [accessed 2021-01-09]

21. Ford EW, Hesse BW, Huerta TR. Personal Health Record Use in the United States: Forecasting Future Adoption Levels. J Med Internet Res 2016 Mar 30;18(3):e73. [doi: 10.2196/jmir.4973]

22. ONC. U.S. Hospital Adoption of Patient Engagement Functionalities. Healthit.gov. 2016. URL: https://dashboard.healthit.gov/ quickstats/pages/FIG-Hospital-Adoption-of-Patient-Engagement-Functionalities.php [accessed 2021-01-09]

23. ONC. Office-based Physician Electronic Patient Engagement Capabilities. Healthit.gov. 2016. URL: dashboard.healthit.gov/ quickstats/pages/physicians-view-download-transmit-secure-messaging-patient-engagement.php [accessed 2021-01-09]

24. Centers for Medicare and Medicaid Services. CLIA program and HIPAA privacy rule; patients' access to test reports. Federal register 2014;79:7289-7316. [doi: 10.1201/b17548-8]

25. Zhao J, Song B, Anand E, Schwartz D, Panesar M, Jackson GP, et al. Barriers, Facilitators, and Solutions to Optimal Patient Portal and Personal Health Record Use: A Systematic Review of the Literature. AMIA Annu Symp Proc 2017;2017:1913-1922 [FREE Full text] [Medline: 29854263]

26. Emani S, Yamin CK, Peters E, Karson AS, Lipsitz SR, Wald JS, et al. Patient Perceptions of a Personal Health Record: A Test of the Diffusion of Innovation Model. J Med Internet Res 2012 Nov 05;14(6):e150. [doi: 10.2196/jmir.2278]

27. King G, Maxwell J, Karmali A, Hagens S, Pinto M, Williams L, et al. Connecting Families to Their Health Record and Care Team: The Use, Utility, and Impact of a Client/Family Health Portal at a Children's Rehabilitation Hospital. J Med Internet Res 2017 Apr 06;19(4):e97. [doi: 10.2196/jmir.6811]

28. Jackman K, Latkin CA, Maksut JL, Trent ME, Sanchez TH, Baral SD. Patient Portals as Highly Acceptable Tools to Support HIV Preventative Behaviors Among Adolescent and Young Sexual Minority Men. Journal of Adolescent Health 2020 Aug;67(2):278-281. [doi: 10.1016/j.jadohealth.2020.03.029] 
29. Jackman KP, Hightow-Weidman L, Poteat T, Wirtz AL, Kane JC, Baral SD. Evaluating psychometric determinants of willingness to adopt sexual health patient portal services among black college students: A mixed-methods approach. Journal of American College Health 2019 Nov 11:1-8. [doi: 10.1080/07448481.2019.1660352]

30. Jackman K, Baral SD, Hightow-Weidman L, Poteat T. Uncovering a Role for Electronic Personal Health Records in Reducing Disparities in Sexually Transmitted Infection Rates Among Students at a Predominantly African American University: Mixed-Methods Study. JMIR Med Inform 2018 Jul 12;6(3):e41. [doi: 10.2196/medinform.9174]

31. CDC. Reported STDs in the United States, 2016 High Burden of STDs Threaten Millions of Americans. CDC. 2017. URL: https://www.google.com/url?sa=t\&rct=j\&q=\&esrc=s\&source=web\&cd=\&ved=2ahUKEwik807Vh4 uAhXrwVkKHT NCH0QFjABegQIARAC\&url=https\%3A\%2F\%2Fstacks.cdc.gov\%2Fview\%2Fcdc\%2F48599\%2Fcdc 48599 DS1. pdf\%3F\&usg=AOvVaw3iT_Ry7mbDSGUYvox3OCvs [accessed 2021-01-09]

32. CDC. New CDC Report: STDs Continue to Rise in the U.S. NCHHSTP Newsroom 2019; Accessed 07/24/2020. NCHHSTP Newsroom. 2019. URL: https://www.cdc.gov/nchhstp/newsroom/2019/2018-STD-surveillance-report-press-release.html [accessed 2021-01-09]

33. Młynarczyk-Bonikowska B, Majewska A, Malejczyk M, Młynarczyk G, Majewski S. Multiresistant Neisseria gonorrhoeae: a new threat in second decade of the XXI century. Med Microbiol Immunol 2019 Dec 04;209(2):95-108. [doi: 10.1007/s00430-019-00651-4]

34. CDC. Sexually Transmitted Disease Surveillance 2018. CDC. Atlanta: U.S. Department of Health and Human Services; 2019. URL: https://www.cdc.gov/std/stats18/STDSurveillance2018-full-report.pdf [accessed 2021-01-09]

35. CDC. Preexposure prophylaxis for the prevention of HIV infection in the United States - 2017 Update. CDC 2018:1-77.

36. National Institute of Allergy and Infectious Disease. HIV Undetectable=Untransmittable (U=U), or Treatment as Prevention. naid.nih.gov. 2019. URL: https://www.niaid.nih.gov/diseases-conditions/treatment-prevention [accessed 2021-01-09]

37. CDC. Gay, Bisexual,Other MSM. CDC. 2015. URL: https://www.cdc.gov/std/life-stages-populations/msm.htm [accessed 2021-01-09]

38. CDC. HIV Surveillance Report, 2018 (Updated). CDC. 2020. URL: http://www.cdc.gov/hiv/library/reports/hiv-surveillance. html [accessed 2021-01-09]

39. Golub SA, Gamarel KE. The Impact of Anticipated HIV Stigma on Delays in HIV Testing Behaviors: Findings from a Community-Based Sample of Men Who Have Sex with Men and Transgender Women in New York City. AIDS Patient Care and STDs 2013 Nov;27(11):621-627. [doi: 10.1089/apc.2013.0245]

40. Fisher CB, Fried AL, Macapagal K, Mustanski B. Patient-Provider Communication Barriers and Facilitators to HIV and STI Preventive Services for Adolescent MSM. AIDS Behav 2018 Mar 15;22(10):3417-3428. [doi: 10.1007/s10461-018-2081-x]

41. Sullivan KA, Berger MB, Quinlivan EB, Parnell HE, Sampson LA, Clymore JM, et al. Perspectives from the Field. Journal of the International Association of Providers of AIDS Care (JIAPAC) 2016 Jul 09;15(6):477-485. [doi:

$10.1177 / 2325957415617830]$

42. Vreeman RC, McCoy BM, Lee S. Mental health challenges among adolescents living with HIV. Journal of the International AIDS Society 2017 May 16;20:21497. [doi: 10.7448/ias.20.4.21497]

43. Gokhale RH, Weiser J, Sullivan PS, Luo Q, Shu F, Bradley H. Depression Prevalence, Antidepressant Treatment Status, and Association with Sustained HIV Viral Suppression Among Adults Living with HIV in Care in the United States, 2009-2014. AIDS Behav 2019 Jul 31;23(12):3452-3459. [doi: 10.1007/s10461-019-02613-6]

44. Beyrer C, Sullivan PS, Sanchez J, Dowdy D, Altman D, Trapence G, et al. A call to action for comprehensive HIV services for men who have sex with men. The Lancet 2012 Jul;380(9839):424-438. [doi: 10.1016/s0140-6736(12)61022-8]

45. Sullivan PS, Driggers R, Stekler JD, Siegler A, Goldenberg T, McDougal SJ, et al. Usability and Acceptability of a Mobile Comprehensive HIV Prevention App for Men Who Have Sex With Men: A Pilot Study. JMIR Mhealth Uhealth 2017 Mar 09;5(3):e26. [doi: 10.2196/mhealth.7199]

46. Luque AE, van Keken A, Winters P, Keefer MC, Sanders M, Fiscella K. Barriers and Facilitators of Online Patient Portals to Personal Health Records Among Persons Living With HIV: Formative Research. JMIR Res Protoc 2013 Jan 22;2(1):e8. [doi: 10.2196/resprot.2302]

47. Hoque MR, Bao Y, Sorwar G. Investigating factors influencing the adoption of e-Health in developing countries: A patient's perspective. Informatics for Health and Social Care 2016 Feb 11;42(1):1-17. [doi: 10.3109/17538157.2015.1075541]

48. Tavares J, Oliveira T. New Integrated Model Approach to Understand the Factors That Drive Electronic Health Record Portal Adoption: Cross-Sectional National Survey. J Med Internet Res 2018 Nov 19;20(11):e11032. [doi: 10.2196/11032]

49. Sanchez TH, Sineath RC, Kahle EM, Tregear SJ, Sullivan PS. The Annual American Men's Internet Survey of Behaviors of Men Who Have Sex With Men in the United States: Protocol and Key Indicators Report 2013. JMIR Public Health Surveill 2015 Apr 17;1(1):e3. [doi: 10.2196/publichealth.4314]

50. Jackman KM, Murray S, Hightow-Weidman L, Trent ME, Wirtz AL, Baral SD, et al. Digital technology to address HIV and other sexually transmitted infection disparities: intentions to disclose online personal health records to sex partners among students at a historically Black college. PLoS One 2020;15(8):e0237648 [FREE Full text] [doi: 10.1371/journal.pone.0237648] [Medline: 32822360] 
51. Wootton AR, Legnitto DA, Gruber VA, Dawson-Rose C, Neilands TB, Johnson MO, et al. Telehealth and texting intervention to improve HIV care engagement, mental health and substance use outcomes in youth living with HIV: a pilot feasibility and acceptability study protocol. BMJ Open 2019 Jul 16;9(7):e028522. [doi: 10.1136/bmjopen-2018-028522]

52. Sullivan S, Sullivan P, Stephenson R. Acceptability and Feasibility of a Telehealth Intervention for Sexually Transmitted Infection Testing Among Male Couples: Protocol for a Pilot Study. JMIR Res Protoc 2019 Oct 1;8(10):e14481. [doi: 10.2196/14481]

53. Muessig K, Knudston K, Soni K. 'I didn't tell you sooner because I didn't know how to handle it myself.' developing a virtual reality program to support HIV-status disclosure decisions. Digit Cult Educ 2018;10:22-48. [Medline: 30123342]

54. Grossman L, Masterson Creber RM, Benda NC, Wright D, Vawdrey DK, Ancker JS. Interventions to increase patient portal use in vulnerable populations: a systematic review. J Am Med Inform Assoc 2019:855-870. [doi: 10.1093/jamia/ocz023] [Medline: 30958532]

55. Muessig K, LeGrand S, Horvath K, Bauermeister J, Hightow-Weidman L. Recent mobile health interventions to support medication adherence among HIV-positive MSM. Current Opinion in HIV and AIDS 2017;12(5):432-441. [doi: 10.1097/coh.0000000000000401] [Medline: 28639990]

56. Liu A, Coleman K, Bojan K, Serrano PA, Oyedele T, Garcia A, et al. Developing a Mobile App (LYNX) to Support Linkage to HIV/Sexually Transmitted Infection Testing and Pre-Exposure Prophylaxis for Young Men Who Have Sex With Men: Protocol for a Randomized Controlled Trial. JMIR Res Protoc 2019 Jan 25;8(1):e10659. [doi: 10.2196/10659] [Medline: $\underline{30681964]}$

57. LeGrand S, Muessig K, Horvath K, Rosengren A, Hightow-Weidman L. Using technology to support HIV self-testing among MSM. Current Opinion in HIV and AIDS 2017;12(5):425-431. [doi: 10.1097/coh.0000000000000400] [Medline: 28617712]

58. Lu AS, Kharrazi H. A State-of-the-Art Systematic Content Analysis of Games for Health. Games for Health Journal 2018 Feb;7(1):1-15. [doi: 10.1089/g4h.2017.0095] [Medline: 29293368]

59. Franklin S, Gibson D, Robertson P, Pohlmann J, Fralish J. Parallel Analysis: a Method for Determining Significant Principal Components Recommended Citation. Journal of Vegetation Science 1995;6(1):99-106. [doi: 10.2307/3236261]

60. Kaiser HF. An index of factorial simplicity. Psychometrika 1974 Mar;39(1):31-36. [doi: 10.1007/bf02291575]

61. Hu L, Bentler PM. Cutoff criteria for fit indexes in covariance structure analysis: Conventional criteria versus new alternatives. Structural Equation Modeling: A Multidisciplinary Journal 1999 Jan;6(1):1-55. [doi: 10.1080/10705519909540118]

62. Hair J, Black W, Babin B, Anderson R. Multivariate Data Analysis (seventh edition). Upper Saddle River, NJ: Prentice Hall; 2019.

63. Kessler RC, Green JG, Gruber MJ, Sampson NA, Bromet E, Cuitan M, et al. Screening for serious mental illness in the general population with the K6 screening scale: results from the WHO World Mental Health (WMH) survey initiative. Int. J. Methods Psychiatr. Res 2011 Feb 24;20(1):62-62. [doi: 10.1002/mpr.333]

64. Brown JD. Choosing the Right Type of Rotation in PCA and EFA. Shiken: JALT Testing \& Evaluation SIG Newsletter 2009;13(3):20-25.

65. DiStefano C, Zhu M, Mindrila D. Understanding and Using Factor Scores: Considerations for the Applied Researcher. Practical Assessment, Research \& Evaluation 2009;14(20):1-11.

66. Saberi P, Dawson Rose C, Wootton AR, Ming K, Legnitto D, Jeske M, et al. Use of technology for delivery of mental health and substance use services to youth living with HIV: a mixed-methods perspective. AIDS Care 2019 May 28;32(8):931-939. [doi: 10.1080/09540121.2019.1622637]

67. Advisory Committee on Immunization Practices (ACIP), Fiore AE, Wasley A, Bell BP. Prevention of hepatitis A through active or passive immunization: recommendations of the Advisory Committee on Immunization Practices (ACIP). MMWR Recomm Rep 2006 May 19;55(RR-7):1-23 [FREE Full text] [Medline: 16708058]

68. Schillie S, Vellozzi C, Reingold A, Harris A, Haber P, Ward JW, et al. Prevention of Hepatitis B Virus Infection in the United States: Recommendations of the Advisory Committee on Immunization Practices. MMWR Recomm. Rep 2018 Jan 12;67(1):1-31. [doi: 10.15585/mmwr.rr6701a1]

69. Weinbaum CM, Mast EE, Ward JW. Recommendations for identification and public health management of persons with chronic hepatitis B virus infection. Hepatology 2009 Apr 27;49(S5):S35-S44. [doi: 10.1002/hep.22882]

70. Otsuka SH, Tayal NH, Porter K, Embi PJ, Beatty SJ. Improving Herpes Zoster Vaccination Rates Through Use of a Clinical Pharmacist and a Personal Health Record. Am J Med 2013 Sep;126(9):832.e1-832.e6. [doi: 10.1016/j.amjmed.2013.02.018]

71. Cohall A, Zucker J, Krieger R, Scott C, Guido C, Hakala S, et al. Missed Opportunities for Hepatitis A Vaccination Among MSM Initiating PrEP. J Community Health 2019 Nov 13;45(3):506-509. [doi: 10.1007/s10900-019-00768-w]

72. Foster MA, Hofmeister MG, Kupronis BA, Lin Y, Xia G, Yin S, et al. Increase in Hepatitis A Virus Infections — United States, 2013-2018. MMWR Morb Mortal Wkly Rep 2019 May 10;68(18):413-415. [doi: 10.15585/mmwr.mm6818a2]

73. Tram J, Le Baccon - Sollier P, Bolloré K, Ducos J, Mondain A, Pastor P, et al. RNA testing for the diagnosis of acute hepatitis A during the 2017 outbreak in France. J Viral Hepat 2020 May;27(5):540-543. [doi: 10.1111/jvh.13255]

74. Raczyńska A, Wickramasuriya NN, Kalinowska-Nowak A, Garlicki A, Bociagga-Jasik M. Acute Hepatitis A Outbreak Among Men Who Have Sex With Men in Krakow, Poland; February 2017-February 2018. Am J Mens Health 2019 Dec 26;13(6):155798831989514. [doi: 10.1177/1557988319895141] 
75. Sachdeva H, Benusic M, Ota S, Stuart R, Maclachlan J, Dubey V, et al. Community outbreak of hepatitis A disproportionately affecting men who have sex with men in Toronto, Canada, January 2017-November 2018. Can Commun Dis Rep 2019 Oct 3;45(10):262-268. [doi: 10.14745/ccdr.v45i10a03]

76. Marcus JL, Hurley LB, Krakower DS, Alexeeff S, Silverberg MJ, Volk JE. Use of electronic health record data and machine learning to identify candidates for HIV pre-exposure prophylaxis: a modelling study. The Lancet HIV 2019 Oct;6(10):e688-e695. [doi: 10.1016/s2352-3018(19)30137-7]

77. Yang C, Linas B, Kirk G, Bollinger R, Chang L, Chander G, et al. Feasibility and Acceptability of Smartphone-Based Ecological Momentary Assessment of Alcohol Use Among African American Men Who Have Sex With Men in Baltimore. JMIR mHealth uHealth 2015 Jun 17;3(2):e67. [doi: 10.2196/mhealth.4344]

78. Cronin R, Conway D, Condon D, Jerome R, Byrne D, Harris P. Patient and healthcare provider views on a patient-reported outcomes portal. J Am Med Inform Assoc 2018 Nov 01;25(11):1470-1480. [doi: 10.1093/jamia/ocy111] [Medline: 30239733]

79. Wu AW, Kharrazi H, Boulware LE, Snyder CF. Measure once, cut twice-adding patient-reported outcome measures to the electronic health record for comparative effectiveness research. Journal of Clinical Epidemiology 2013 Aug;66(8):S12-S20. [doi: 10.1016/j.jclinepi.2013.04.005]

80. Goyal MK, Fein JA, Badolato GM, Shea JA, Trent ME, Teach SJ, et al. A Computerized Sexual Health Survey Improves Testing for Sexually Transmitted Infection in a Pediatric Emergency Department. J Pediatr 2017 Apr;183:147-152.e1. [doi: 10.1016/j.jpeds.2016.12.045]

\author{
Abbreviations \\ AMIS: American Men's Internet Survey \\ CFA: confirmatory factor analysis \\ CFI: comparative fit index \\ EFA: exploratory factor analysis \\ EHR: electronic health record \\ eSHINE: Electronic Sexual Health Information Notification and Education \\ Health IT: Health information technology \\ HINTS: Health Information National Trends Survey \\ KMO: Kaiser-Meyer-Olkin \\ K6: Kessler 6-item psychological distress scale \\ mHealth: mobile health \\ ONC: Office of the National Coordinator for Health Information Technology \\ PCA: principal component analysis \\ PHR: personal health record \\ PPI: patient portal instrument \\ PPSHI: patient portal sexual health instrument \\ PrEP: pre-exposure prophylaxis \\ RMSEA: root mean square error of approximation \\ SMM: sexual minority men \\ SRMR: standardized root mean square residual \\ STD: sexually transmitted disease \\ STI: sexually transmitted infection \\ TLI: Tucker-Lewis index
}

Edited by $G$ Eysenbach; submitted 16.03.20; peer-reviewed by S Naar, G Strudwick; comments to author $17.06 .20 ;$ revised version
received 24.07.20; accepted 26.10.20; published 10.02.21
Please cite as:
Jackman KMP, Kane J, Kharrazi H, Johnson RM, Latkin C
Using the Patient Portal Sexual Health Instrument in Surveys and Patient Questionnaires Among Sexual Minority Men in the United
States: Cross-sectional Psychometric Validation Study
J Med Internet Res 2021;23(2):e18750
URL: $\underline{\text { http://www.jmir.org/2021/2/e18750/ }}$
doi: $\underline{10.2196 / 18750}$
PMID: $\underline{33565987}$ 
CKevon-Mark P Jackman, Jeremy Kane, Hadi Kharrazi, Renee M Johnson, Carl Latkin. Originally published in the Journal of Medical Internet Research (http://www.jmir.org), 10.02.2021. This is an open-access article distributed under the terms of the Creative Commons Attribution License (https://creativecommons.org/licenses/by/4.0/), which permits unrestricted use, distribution, and reproduction in any medium, provided the original work, first published in the Journal of Medical Internet Research, is properly cited. The complete bibliographic information, a link to the original publication on http://www.jmir.org/, as well as this copyright and license information must be included. 